\title{
An Effective Passive Solar Dryer for Thin Layer Drying of Poultry Manure
}

\author{
A. E. Ghaly and K. N. MacDonald \\ Department of Process Engineering and Applied Science, Dalhousie University, Halifax, Nova Scotia, Canada \\ Email: abdel.ghaly@dal.ca
}

Received 2012-07-30, Revised 2012-08-02; Accepted 2012-08-04

\begin{abstract}
Animal and poultry manures have been recognized for centuries as organic fertilizers providing essential nutrients to crops and improving soil structure due to their large input of organic matter. Increasing demand for poultry and egg products has led to intensification of the poultry rearing process, resulting in large amounts of poultry manure. Drying can be used to reduce the environmental impact of poultry manure and create a value added product for the farmers (animal feed or organic fertilizer). The aim of this study was to investigate the effect of solar heated air drying on the chemical and biological characteristics of poultry manure and develop a suitable manure solar dryer. The effects of temperature $\left(40-60^{\circ} \mathrm{C}\right)$ and manure layer depth $(1-3 \mathrm{~cm})$ were evaluated. At the three temperature levels studied, the time required to dry poultry manure in the $1 \mathrm{~cm}$-deep layer was the shortest, followed by the 2 and $3 \mathrm{~cm}$-deep layers, respectively. The optimum depth to dry manure (at which the highest drying effectiveness occurred) was $3 \mathrm{~cm}$. The manure drying rate increased with increasing temperature and was the fastest at $60^{\circ} \mathrm{C}$ for all manure depths studied. A drying temperature-depth combination of $60^{\circ} \mathrm{C}$ and $3 \mathrm{~cm}$ was the most efficient for the thin layer drying of poultry manure. Drying poultry manure at these conditions provided an effective means of removing moisture and odor and destroying microorganisms, thereby allowing the production of a value added product. This temperature range is feasible with a solar dryer operating in the tropics. A solar dryer operating at a $3 \mathrm{~cm}$ manure depth would be capable of drying $336 \mathrm{~kg} / \mathrm{h}$. Drying poultry manure with solar heated air resulted in a slight decrease in protein content (from 42 to $41 \%$ ), a decrease in pH (from 8.4 to 6.6), removal of Salmonellae and a $99 \%$ reduction in numbers of total bacteria, yeast, mold and $E$. coli. Thin layer solar drying of poultry manure proved to be an effective means of converting poultry manure into a value added product while reducing the environmental and health problems that are associated with current disposal options.
\end{abstract}

Keywords: Poultry Manure; Solar Drying; Solar Radiation; Mass and Heat Balance; Odor; Pathogens; Nutrients; Moisture Content

\section{INTRODUCTION}

Animal and poultry manures have been recognised for centuries as organic fertilizers providing essential nutrients to crops and improving soil structure due to their large input of organic matter. However, the increasing production of animal and poultry products to meet the demands of an ever increasing population has

resulted in large livestock and poultry operations that produce large amounts of manure making its storage and disposal an environmental and health problem. Improper handling and disposal of manure can cause air, water and soil pollution, result in spreading of animal pathogens, deteriorating habitat and eliminating biodiversity (Benali and Kudra, 2002).

The economics of scale in livestock and poultry production have resulted in increased animal and bird densities that created manure management challenges for farmers and scientists throughout the world. This issue is particularly pressing with poultry production facilities as their farms typically manage little or no crop land and the produced manure poses serious environmental problems. As a result, the poultry industry is facing challenges related to the treatment and disposal of manure as the public is becoming less tolerant of environmental problems (Fugere et al., 
2007). Poultry manure begins to decompose immediately after excretion giving off ammonia which, in high concentrations, can have adverse effects on the health and productivity of birds as well as health of farm workers (Zhang and Lau, 2007; Amon et al., 2006). Manure can also serve as a breeding ground for pathogenic microorganisms as well as a medium for disease transmission among birds. Flies and other undesirable insects can breed on manure leading to health hazards and nuisances associated with them (Lay et al., 2011; Axtell, 1999). Manure is also a source of odor caused by the activity of microorganisms in the manure (Berry and Miller, 2005; Fares et al., 2005).

Furthermore, manure cannot be applied onto frozen land in Canada and must be stored for 6-8 months. Organic acids produced by fermentation during manure storage have been implicated in the inhibition of seed germination (Iannotti et al., 1994). Also hydrogen sulfide and greenhouse gasses such as methane and nitrous oxide are produced during storage (Brock and Madigan, 1991; Choi et al., 2001; Pel et al., 1997). It is, therefore, necessary to subject poultry manure to some treatments in order to improve its storage and handling properties and to minimize the risk of disease transmission and environmental pollution. Proper poultry manure management systems that will preserve the environment, contribute to animal and human health and return a profit on investment to farmers need to be developed.

Drying can convert poultry manure into a safe product that can be used as organic fertilizer or animal feed (Thomas et al., 1972; Alam et al., 2008). By drying, deterioration from chemical and biological activity is minimized and the environmental problems associated with decomposition of raw manure can be prevented. Drying also removes manure stickiness and hence makes its handling easier (Bernhart and Fasina, 2009). Drying with heated air offers a number of advantages over unheated air drying including: higher rate of oxidation and destruction of pathogens (Cummings and Jewell, 1977).

Drying with heated air can be carried out using a variety of heat sources such as solar energy, natural gas, or other fossil fuels. However, solar energy offers several advantages over other energy sources: (a) it is available in abundance all year round, (b) it has a higher rate of oxidation, (c) it results in good odor control and waste stabilization and (d) it has a higher rate of pathogen destruction (McCaskey and Wang, 1985; Amine-Khodja et al., 2006; Martens and Bohm, 2009). Properly designed solar drying systems must take into account the drying requirements for specific products, energy efficiency and cost effectiveness (Tiris et al.,
1994; Diamante and Munro, 1993; Nellist, 1987).

The main objectives of this study were to: (a) determine the optimum drying rate of laying hen manure at a temperature range of $40-60^{\circ} \mathrm{C}$ and manure layer depth in the range of 1-3 cm, (b) determine the changes in the manure properties due to drying and (c) design a passive solar manure dryer.

\section{KINETICS OF SOLAR MANURE DRYER}

The abundant supply of solar energy could be used to provide the energy required to dry poultry manure and thus reduce the pollution problems associated with manure disposal. The most important element in a solar dryer is the solar collector which determines the amount of heat energy that may be trapped from the sun for the drying operation and the amount of water to be removed from the manure on a daily basis.

\subsection{Mass Balance}

If an amount of manure $\left(\mathrm{W}_{\mathrm{m}}\right)$ at initial moisture content $\left(\mathrm{M}_{\mathrm{i}}\right)$ and temperature $\left(\mathrm{T}_{\mathrm{i}}\right)$ is to be dried to a final moisture content $\left(\mathrm{M}_{\mathrm{f}}\right)$ at a temperature $\left(\mathrm{T}_{\mathrm{f}}\right)$ in a given time $(t)$, the manure feed rate $\left(W_{r}\right)$ into the dryer can be calculated as follows:

$\mathrm{W}_{\mathrm{r}}=\frac{\mathrm{W}_{\mathrm{m}}}{\mathrm{t}}$

Where:

$\mathrm{W}_{\mathrm{r}}=$ The manure feed rate $(\mathrm{kg} / \mathrm{d})$

$\mathrm{W}_{\mathrm{m}}=$ The amount of manure to be dried $(\mathrm{kg})$

$\mathrm{T}=$ Time $(\mathrm{d})$

The amount of moisture entering the system daily $\left(\mathrm{W}_{\mathrm{w}}\right)$ is calculated as follows:

$\mathrm{W}_{\mathrm{w}}=\frac{\mathrm{M}_{\mathrm{i}} \mathrm{W}_{\mathrm{r}}}{100}$

Where:

$\mathrm{M}_{\mathrm{i}}=$ Initial moisture content (\% wet basis)

$\mathrm{W}_{\mathrm{w}}=$ Amount of moisture entering the system $(\mathrm{kg} / \mathrm{d})$

The amount of dry matter $\left(\mathrm{W}_{\mathrm{s}}\right)$ that passes through the system is calculated as follows:

$\mathrm{W}_{\mathrm{s}}=\mathrm{W}_{\mathrm{r}}\left(1-\frac{\mathrm{M}_{\mathrm{i}}}{100}\right)$

Where: 
$\mathrm{W}_{\mathrm{s}}=$ Amount of dry matter entering the system $(\mathrm{kg} / \mathrm{d})$

Hence, the amount of moisture to be removed $\left(\mathrm{M}_{\mathrm{r}}\right)$ is calculated as follows:

$M_{r}=W_{r}\left(\frac{M_{i}-M_{f}}{100}\right)$

Where:

$\mathrm{M}_{\mathrm{r}}=$ Amount of moisture to be removed ( $\left.\mathrm{kg} / \mathrm{d}\right)$

$\mathrm{M}_{\mathrm{f}}=$ Final moisture content ( $\%$ wet basis)

\subsection{Heat Balance}

The heat energy required for drying can be determined as follows:

$$
\begin{aligned}
\text { Heat required } & =\left[\begin{array}{l}
\text { Heat required to rise } \\
\text { the temperature of dry } \\
\text { matter from } \mathrm{T}_{\mathrm{i}} \text { to } \mathrm{T}_{\mathrm{f}}
\end{array}\right]+ \\
& {\left[\begin{array}{l}
\text { Heat required to raise } \\
\text { the temperature of } \\
\text { moisture from } \mathrm{T}_{\mathrm{i}} \text { to } \mathrm{T}_{\mathrm{f}}
\end{array}\right]+} \\
& {\left[\begin{array}{l}
\text { Heat required to } \\
\text { evaporate the moisture } \\
\text { at temperature } \mathrm{T}_{\mathrm{f}}
\end{array}\right] }
\end{aligned}
$$

Mathematically, Eq. 5 can be written as follows:

$$
\begin{aligned}
Q= & \mathrm{W}_{\mathrm{r}}\left[\mathrm{Cp}_{\mathrm{s}}\left(1-\frac{\mathrm{M}_{\mathrm{i}}}{100}\right)+\mathrm{Cp}_{\mathrm{w}} \frac{\mathrm{M}_{\mathrm{i}}}{100}\right]\left(\mathrm{T}_{\mathrm{i}}-\mathrm{T}_{\mathrm{f}}\right)+ \\
& \mathrm{h}_{\mathrm{v}}\left(\frac{\mathrm{M}_{\mathrm{i}}-\mathrm{M}_{\mathrm{f}}}{100}\right)
\end{aligned}
$$

Where:

$\mathrm{Cp}_{\mathrm{s}}=$ specific heat capacity of dry matter $\left(\mathrm{KJ} / \mathrm{kg}^{\circ} \mathrm{C}\right)$

$\mathrm{Cp}_{\mathrm{w}}=$ specific heat capacity of water $\left(\mathrm{KJ} / \mathrm{kg}^{\circ} \mathrm{C}\right)$

$\mathrm{h}_{\mathrm{v}}=$ latent heat of vaporization of water at temperature $\mathrm{T}_{\mathrm{f}}(\mathrm{KJ} / \mathrm{kg})$

$\mathrm{Q}=$ heat energy requirement $(\mathrm{KJ} /$ day $)$

$\mathrm{T}_{\mathrm{i}}=$ initial temperature $\left({ }^{\circ} \mathrm{C}\right)$

$\mathrm{T}_{\mathrm{f}}=$ Final temperature $\left({ }^{\circ} \mathrm{C}\right)$

If the heat energy required for drying is to be met completely by solar radiation, then:

$\mathrm{Q}=\mathrm{H}_{\beta} \mathrm{A}_{\mathrm{c}}$

Where:

Science Publications

$\mathrm{A}_{\mathrm{c}}=$ solar collector area $\left(\mathrm{m}^{2}\right)$

$\mathrm{H}_{\beta}=$ average solar radiation incident on a surface tilted at an angle $\beta$ to the horizontal $\left(\mathrm{KJ} / \mathrm{m}^{2} \mathrm{~d}\right)$

$\beta=$ slope of collector (degrees)

Equation 7 can be rewritten as follows:

$$
\mathrm{A}_{\mathrm{c}}=\frac{\mathrm{Q}}{\mathrm{H}_{\beta}}
$$

The incident solar radiation $\mathrm{H}_{\beta}$ is estimated from the following equation (Duffie and Beckman, 1980):

$$
\mathrm{H}_{\beta}=\mathrm{H}_{\mathrm{b}} \mathrm{R}_{\mathrm{b}}\left(\overline{\tau_{\beta}}\right)_{\mathrm{b}, \mathrm{e}}+\left(\mathrm{H}_{\mathrm{d}} \mathrm{R}_{\mathrm{s}}+\mathrm{H}_{\rho} \mathrm{R}_{\mathrm{g}}\right)\left(\overline{\tau_{\alpha}}\right)_{\mathrm{d}, \mathrm{e}}
$$

$$
\begin{aligned}
& \text { Where: } \\
& \mathrm{H}_{\mathrm{b}} \quad=\text { estimated mean daily solar radiation on a } \\
& \text { horizontal surface }\left(\mathrm{KJ} / \mathrm{m}^{2} \mathrm{~d}\right) \\
& \mathrm{H}_{\mathrm{d}} \quad=\text { estimated mean daily diffuse solar radiation } \\
& \text { on a horizontal surface }\left(\mathrm{KJ} / \mathrm{m}^{2} \mathrm{~d}\right) \\
& \mathrm{H}_{\rho} \quad=\text { measured mean daily total solar radiation on a } \\
& \text { horizontal surface }\left(\mathrm{KJ} / \mathrm{m}^{2} \mathrm{~d}\right) \\
& \mathrm{R}_{\mathrm{b}} \quad=\text { correction factor for beam radiation on tilted }
\end{aligned}
$$

Cairo lies on latitude $30^{\circ} 2^{\prime} \mathrm{N}$ and longitude $31^{\circ}$ $13^{\prime}$ E. The mean daily solar irradiation on a horizontal surface in Cairo varies between $11.94 \mathrm{MJ} / \mathrm{m}^{2} / \mathrm{d}$ in December to $27.3 \mathrm{MJ} / \mathrm{m}^{2} / \mathrm{d}$ in June. Daylight duration varies from 11.68 hours in mid-December to 12.56 hours in mid-June with about 300 days per year of clear sky. The measured mean daily total solar radiation on a horizontal surface $\mathrm{H}_{\rho}$ was taken as $11.94 \mathrm{MJ} / \mathrm{m}^{2} \mathrm{~d}$ which represents the yearly minimum monthly average daily solar radiation on a horizontal surface. $\mathrm{H}_{\mathrm{d}}$ was estimated from $\mathrm{H}_{\rho}$ using the method of Liu and Jordan (1960). $\mathrm{H}_{b}$ was determined as the difference between $\mathrm{H}_{\rho}$ and $\mathrm{H}_{\mathrm{d}}$. $\mathrm{R}_{\mathrm{b}}, \quad \mathrm{R}_{\mathrm{g}}, \quad \mathrm{R}_{\mathrm{s}}, \quad\left(\tau_{\beta}\right)_{\mathrm{b}, \mathrm{e}}$ and $\left(\tau_{\alpha}\right)_{\mathrm{d}, \mathrm{e}}$ were determined according to the method given by Duffie and Beckman (1980). The initial temperature of the manure $\left(T_{i}\right)$ was assumed to be equal to the ambient temperature $\left(30^{\circ} \mathrm{C}\right)$. 
Table 1. Parameters used in the estimated of collector size.

\begin{tabular}{lll}
\hline Parameter & Value & Comments \\
\hline $\mathrm{H}$ & $11.49 \mathrm{MJ} / \mathrm{m}^{2} \mathrm{~d}$ & Yearly minimum average daily total radiation on a horizontal surface \\
$\mathrm{H}_{\mathrm{b}}$ & $5.29 \mathrm{MJ} / \mathrm{m}^{2} \mathrm{~d}$ & Estimated from H \\
$\mathrm{H}_{\mathrm{d}}$ & $6.65 \mathrm{MJ} / \mathrm{m}^{2} \mathrm{~d}$ & Estimated from H \\
$\mathrm{H}_{\rho}$ & $11.94 \mathrm{MJ} / \mathrm{m}^{2} \mathrm{~d}$ & Average daily extra-terrestrial radiation on a horizontal surface for August in Cairo \\
$\varnothing$ & $6.52^{\circ}$ & Latitude for Cairo \\
$\beta$ & $7.0^{\circ}$ & Slope of collector \\
$\mathrm{D}_{\mathrm{s}}$ & $13.45^{\circ}$ & Solar declination \\
$\mathrm{R}_{\mathrm{b}}$ & 0.9628 & Calculated \\
$\mathrm{R}_{\mathrm{s}}$ & 0.9963 & Calculated \\
$\mathrm{R}_{\mathrm{g}}$ & 0.004 & Calculated \\
$\rho$ & 0.2 & Ground albedo (vegetated ground) \\
$\eta_{\mathrm{ac}}$ & 1.49 & Refractive index for acrylic \\
$\mathrm{K}_{\mathrm{ac}}$ & 25.0 & Extinction coefficient for acrylic \\
$\mathrm{t}_{\mathrm{g}}$ & $0.005 \mathrm{~m}$ & Glazing thickness \\
$\alpha$ & 0.95 & Absorptivity of manure assumed equal to absorptivity of black point \\
$\left(\overline{\tau_{\beta}}\right)_{\mathrm{b}, \mathrm{e}}$ & 0.584 & Calculated \\
$\left(\tau_{\alpha}\right)_{\mathrm{d}, \mathrm{e}}$ & 0.709 & \\
$\mathrm{H}_{\mathrm{T}}$ & $7.68 \mathrm{MJ} / \mathrm{m}^{2} \mathrm{~d}$ & Calculated \\
$\mathrm{M}_{\mathrm{i}}$ & $79.5 \%(\mathrm{wb})$ & Calculated \\
$\mathrm{M}_{\mathrm{f}}$ & $14 \%(\mathrm{wb})$ & Initial moisture content of manure \\
$\mathrm{T}_{\mathrm{i}}$ & $30^{\circ} \mathrm{C}$ & Final moisture content of manure \\
$\mathrm{T}_{\mathrm{f}}$ & $60^{\circ} \mathrm{C}$ & Initial temperature of manure \\
$\mathrm{C} \mathrm{p}_{\mathrm{w}}$ & $4.19 \mathrm{KJ} / \mathrm{kg}^{\circ} \mathrm{C}$ & Final temperature of manure \\
$\mathrm{Cp}$ & $4.19 \mathrm{KJ} / \mathrm{kg}{ }_{\mathrm{s}}^{\circ} \mathrm{C}$ & Specific heat capacity of water \\
$\mathrm{h}_{\mathrm{fg}}$ & 2357.63 & Specific heat capacity of manure (assumed equal to that of water) \\
$\mathrm{W}$ & $10 \mathrm{~kg} / \mathrm{d}$ & Latent heat of vaporization of water at $60^{\circ} \mathrm{C}$ \\
$\mathrm{Q}$ & $19.13 \mathrm{MJ} / \mathrm{d}$ & Manure loading rate \\
\hline & & Daily heat requirement \\
\hline
\end{tabular}

The final (drying) drying temperature $\left(\mathrm{T}_{\mathrm{f}}\right)$ was assumed to be $60^{\circ} \mathrm{C}$ based on flat plate collector absorber temperature records given by El-Sayed (1992). A summary of the parameters used in the estimation of collector area in Eq. 8 are shown in Table 1.

\section{MATERIALS AND METHODS}

\subsection{Trays}

Three sets of trays, each consisting of three trays of the same dimensions, were constructed using galvanized metal sheets for the drying of poultry manure in the laboratory. Each tray had a drying surface areas of 100 $\mathrm{cm}^{2}$. The depths of the trays were $1 \mathrm{~cm}, 2 \mathrm{~cm}$ and $3 \mathrm{~cm}$ for sets 1, 2 and 3, respectively. Fig. 1 shows the dimensions of the drying trays.

\subsection{Manure}

Poultry manure was obtained from a layer house on Archibald Farms located in Stewiack East, approximately $80 \mathrm{~km}$ from Halifax, Nova Scotia. The manure was collected from under the battery cages of a laying house accommodating approximately 50,000 hens. The manure collected was fresh and was not subjected to any treatment on the farm. It was placed in clean plastic bags and transported to the Waste Management Laboratory at Dalhousie University, Halifax, Nova Scotia where it was stored at $-18^{\circ} \mathrm{C}$. Some characteristics of the poultry manure used in this study are presented in Table 2.

\subsection{Experimental Procedure}

The effects of three drying temperatures $(40,50$ and $\left.60^{\circ} \mathrm{C}\right)$ and three manure depths $(1,2$ and $3 \mathrm{~cm})$ on the manure drying rate, drying time and manure characteristics were investigated. The selected temperature range is within the range $\left(35\right.$ to $\left.75^{\circ} \mathrm{C}\right)$ of heated air using solar dryers (El-Sayed, 1992). Prior to placing the manure in the drying trays, it was removed from the freezer and allowed to thaw for 24 hours at room temperature $\left(22^{\circ} \mathrm{C}\right)$. The three sets of trays were weighed using a digital scale (METTLER Balance model PM4600, Fisher Scientific, Montreal, Quebec). The trays were then filled to their respective depths with the manure and weighed again. The filled trays were placed in a forced draft oven (Isotemp Oven Model 655F, Fisher Scientific, Montreal, Quebec) adjusted to the required temperature. 


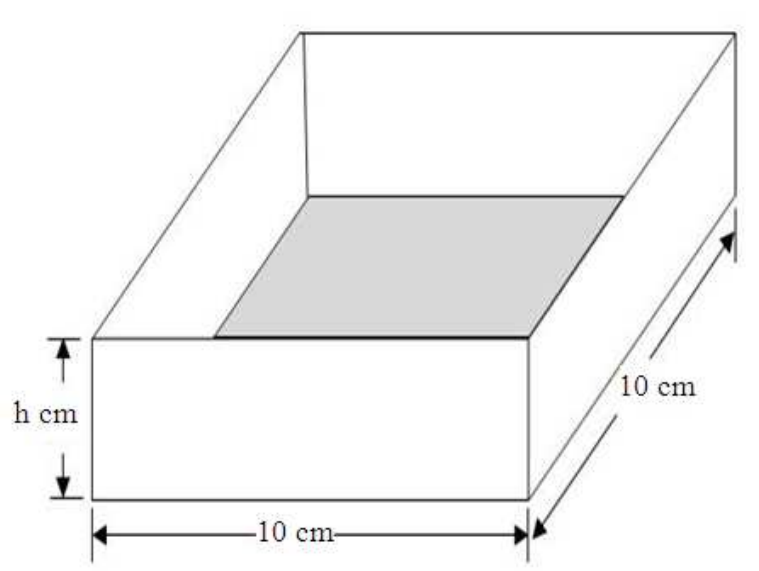

Fig. 1. The dimensions of the drying tray $(\mathrm{h}=1,2$ or 3 $\mathrm{cm})$

The drying rate was monitored by determining the change in weight at 2 hour time intervals until a constant weight was reached. The oven temperature was then readjusted to the next required temperature and the same experimental procedure was followed. Three replicates for each temperature-manure depth combination were carried out.

\subsection{Experimental Analysis}

The moisture content, density, total and volatile solids, total and soluble chemical oxygen demand, total Kjeldahl and ammonium nitrogen, elemental ( $\mathrm{P}, \mathrm{K}, \mathrm{Ca})$, ash, total plate count, pathogen, insect, ordor and $\mathrm{pH}$ analyses were performed on the raw manure. The moisture content, $\mathrm{pH}$, protein, elemental, total plate count, pathogen and odor analyses were performed on the dried samples. The density, total solids and chemical oxygen demand analyses were preformed according to the procedures described in the Standard Methods for Examination of Water and Wastewater (APHA, 1998). The total Kjeldahl and ammonium nitrogen analyses were performed using the Kjeltec Auto Analyser (Model 1030, Toecator, Hoganas, Sweeden) according to the Kjeldahl method. The $\mathrm{pH}$ was measured using a $\mathrm{pH}$ meter (Model 805MV, Fisher Scientific, Montreal, Quebec) according to the procedure described in the Methods of Soil Analysis (ASABE, 2009). The elemental analyses $(\mathrm{Ca}, \mathrm{K}, \mathrm{P})$ were performed in the Mineral Engineering Centre of Dalhousie University, Halifax, Nova Scotia, using flame atomic absorption spectroscopy. The moisture content, protein, microbial and odor analyses were performed as follows.
Table 2. Some characteristics of the poultry manure.

\begin{tabular}{lc}
\hline Item & Measured value \\
\hline Moisture content & $78.4 \%$ \\
Density & $960 \mathrm{~kg} / \mathrm{m}^{3}$ \\
Total solids & $215520 \mathrm{mg} / \mathrm{L}$ \\
Volatile solids & $139770 \mathrm{mg} / \mathrm{L}$ \\
Ash & $75750 \mathrm{mg} / \mathrm{L}$ \\
Total Chemical Oxygen Demand & $328500 \mathrm{mg} / \mathrm{L}$ \\
Soluble Chemical Oxygen & \\
Demand & $130000 \mathrm{mg} / \mathrm{L}$ \\
Total Kjeldahl Nitrogen & $18960 \mathrm{mg} / \mathrm{L}$ \\
Ammonium Nitrogen & $9470 \mathrm{mg} / \mathrm{L}$ \\
Calcium & $19760 \mathrm{mg} / \mathrm{L}$ \\
Phosphorous & $5590 \mathrm{mg} / \mathrm{L}$ \\
Potassium & $4140 \mathrm{mg} / \mathrm{L}$ \\
pH & 8.40 \\
\hline
\end{tabular}

\subsubsection{Moisture Content}

The moisture content was determined using the oven drying method according to the procedure described in the ASABE standards (ASABE, 2009). Samples of approximately $10 \mathrm{~g}$ were dried at $103^{\circ} \mathrm{C}$ for $24 \mathrm{~h}$ in a drying oven (Isotemp Oven Model 655F, Fisher Scientific, Montreal, Quebec) and the moisture contents (MC) were calculated as follows:

$\mathrm{MC}(\% \mathrm{wb})=\frac{(\text { Weight of wet sample }- \text { Weight of dry sample JX100) }}{\text { Weight of wet sample }}$

\subsubsection{Odor}

A specially developed organoleptic test for the measurement of odor from animal waste was used to measure the presence and offensiveness of odor in the dried poultry manure. This method was chosen because the complex nature of manure odor is best judged by the human nose. In this test, scales of $0-10$ were used to rate the odor as to its presence and offensiveness. No odor was assigned a score of 0 and very strong odor was assigned a score of 10. Similarly, no offensive odor was assigned a score of 0 and very offensive odor was assigned a score of 10 . The intermediate numbers 1-9 are described in the score sheet (Fig. 2) which was used by the panel members to rate the samples $(50 \mathrm{~g})$ placed before them in 125 Erlenmeyer flasks. The panel members were asked to rate the contents of the flasks according to the scales $0-10$. The lower limit (0) was assigned to distilled water whereas the upper limit (10) was assigned to fresh poultry manure. The odor testing panel consisted of 10 members, including technicians, graduate and undergraduate students and faculty. Each panel member was asked to rate the samples as to the presence of odor and the odor offensiveness according to the $0-10$ scales and to describe the odor on a separate data sheet. 


\begin{tabular}{|c|c|c|c|}
\hline \multicolumn{4}{|c|}{$\begin{array}{l}\text { A. Rate the samples to the presence of odor and the odor as to offensiveness according to the following } \\
\text { scale using samples " } 0 \text { " as having } 0 \text { rating and samples " } 10 \text { " as having } 10 \text { rating. }\end{array}$} \\
\hline \multirow{2}{*}{\multicolumn{2}{|c|}{ Presence }} & \multicolumn{2}{|c|}{ Offensiveness } \\
\hline & & No offensive odor & 0 \\
\hline Very faint & $1-2$ & Very faint offensive odor & $1-2$ \\
\hline Faint & $3-4$ & Faint offensive odor & $3-4$ \\
\hline Definite & $5-7$ & Definite offensive odor & $5-7$ \\
\hline Strong & $8-9$ & Strong offensive odor & $8-9$ \\
\hline Very strong & 10 & Very strong offensive odor & 10 \\
\hline
\end{tabular}

B. Describe the odor of each sample by giving an appropriate descriptive term. Possible terms that might be used are given in the list below or you may use a term of your choice which you feel properly describes the odor.

$\begin{array}{ll}\text { Mold, musty } & \text { Yeast } \\ \text { Fish } & \text { Ammonia } \\ \text { Stagnant water } & \text { Grain, animal feed } \\ \text { Sulfide, rotten eggs } & \text { Sour, fermented } \\ \text { Petroleum } & \text { Rotten cabbage, mercaptans } \\ \text { Earth } & \text { Other (Please specify) }\end{array}$

\section{RATING}

\begin{tabular}{cccc}
\hline Sample & $\begin{array}{c}\text { Presence } \\
\text { Rating }\end{array}$ & $\begin{array}{c}\text { Offensiveness } \\
\text { Rating }\end{array}$ & $\begin{array}{c}\text { Odor } \\
\text { Description }\end{array}$ \\
\hline 1 & & & \\
\hline 2 & & & \\
\hline 3 & & Thank you for your time
\end{tabular}

Fig 2. Odor evaluation sheet (Ghaly and MacDonald, 2012)

\subsubsection{Total Microbial Count}

Total plate count was employed to estimate the numbers of viable aerobic and facultative microorganisms based on the assumption that each viable cell would develop into a colony after incubation. The manure samples were collected in wide mouth sterilized containers. Each sample was diluted to insure that one of the final plates would have $30-300$ colonies (the range which allows the most accurate approximation of the microbial population). The initial dilution (1:10) was prepared by placing $1 \mathrm{~g}$ on manure into $10 \mathrm{~mL}$ of physiological saline water. The bottle was shaken vigorously to obtain a uniform distribution of organisms.
Further dilutions $\left(1: 10^{3}, 1: 10^{4}, 1: 10^{5}, 1: 10^{6}, 1: 10^{7}\right.$ and $1: 10^{8}$ ) were made by pipetting measured aliquots into physiological saline water. The bottles were thoroughly shaken and $1 \mathrm{~mL}$ of the dilution was pipetted into each labeled (specimen and dilution) petri dish. Samples from each dilution were plated in duplicate. Approximately 15 $\mathrm{mL}$ of cooled melted medium was poured into each petri dish. Immediately thereafter, the plates were gently rotated 6 times in each direction to distribute the inoculum throughout the medium. The plates were allowed to solidify and incubated in the inverted position in an incubator (Model Number 2020, VWR International, Cornelius, Oregon) at $35-37^{\circ} \mathrm{C}$ for 48 hours. Plates that contained $30-300$ colonies were 
selected for counting. An accurate count of the colonies was made by placing the plates on the platform of a colony counter (Cat.No.7-910, Fisher Scientific, Montreal, Quebec). This instrument facilitated the counting process since the colonies were illuminated and viewed against a ruled background. The number of colonies counted and the dilution of the specimen were used to calculate the cell count per milliliter of the specimen.

\subsubsection{Microbial and Insect Analyses}

The following analyses were also performed on the raw and dried manure samples: (a) yeast and mold enumeration (b) E. Coli estimation and (c) Salmonellae examination. These analyses were performed at Nova Scotia Research Foundation Corporation, Dartmouth, Canada.

\subsubsection{Protein}

The total protein content was determined using the Tecator Kjeltec Auto Analyser (Model-1026, Fisher Scientific, Montreal, Quebec). Clean empty tarred beakers were weighed $\left(\mathrm{W}_{1}\right)$ and approximately $1.0 \mathrm{~g}$ of the manure samples (or about $0.5 \mathrm{~g}$ of dried samples) was placed in each of the beakers and reweighed $\left(\mathrm{W}_{2}\right)$. The contents of the beakers were then transferred to macro $250 \mathrm{~mL}$ digestion tubes. One "Kjeltab" (containing $3.5 \mathrm{~g} \mathrm{~K}_{2} \mathrm{SO}_{4}$ and. $0.0035 \mathrm{~g} \mathrm{Se}$ ), $3.0 \mathrm{~mL}$ of distilled water $\left(\mathrm{H}_{2} \mathrm{O}\right), 0.6 \mathrm{~mL}$ of concentrated sulphuric acid $\left(\mathrm{H}_{2} \mathrm{SO}_{4}\right)$ and $0.3 \mathrm{~mL}$ of $30 \%$ hydrogen peroxide $\left(\mathrm{H}_{2} \mathrm{O}_{2}\right)$ were added to the samples in the digestion tubes. The samples were digested at $420^{\circ} \mathrm{C}$ for 30 minutes in a digestion block heater (Tecator Digester Sytem, 20 Model-1016, Fisher Scientific, Montreal, Quebec). The digestion tubes were removed and allowed to cool for 10 minutes. Then, $30 \mathrm{~mL}$ of distilled water were added to the digestion tubes. The test tubes and digests were transferred to the Auto Analyser. The constants A and B for the equipment were set at 0.00 and 1.862, respectively. The titrant acid and the predetermined blank sample were set at $0.2127 \mathrm{M}$ and 0.01 , respectively. Distillations, titrations and calculations were performed automatically. The protein percentage was computed from the following equation:

$$
\text { Total protein }(\%)=\frac{\text { Displayed results }}{\mathrm{W}_{2}-\mathrm{W}_{1}}
$$

\section{RESULTS AND DISCUSSION}

\subsection{Drying Time}

The results (Table 3) indicated that the $1 \mathrm{~cm}$ deep manure layer dried the fastest at all three drying temperatures, followed by the 2 and $3 \mathrm{~cm}$ deep manure layers, respectively. The thinner the manure layer, the lower the amount of moisture it contained and consequently the shorter the time required to drive off the moisture. The times required to dry the $2 \mathrm{~cm}$ deep manure layers were more than the time required to dry the $1 \mathrm{~cm}$ deep manure layers by about $106 \%, 100 \%$ and $87 \%$ while the times required to dry the $3 \mathrm{~cm}$ deep manure layers were more than the times required to dry the $2 \mathrm{~cm}$ deep manure layer by $22 \%, 12 \%$ and $7 \%$ at temperatures of for 40,50 and $60^{\circ} \mathrm{C}$, respectively.

The effect of bed depth on drying rate was investigated by several researchers. Nazghelichi et al. (2010) investigated the effect of bed depth $(30,60$ and $90 \mathrm{~mm}$ ) on the drying of carrot cubes and found the shortest drying time to be achieved at the $30 \mathrm{~mm}$ depth. Maskan et al. (2002) investigated the effect of layer thickness (0.71-2.86 mm) on the drying of fruit leather at various temperatures and air velocities and found the optimum depth to be $0.71 \mathrm{~mm}$. Ertekin and Yaldiz (2004) investigated the effect of slice thickness $(0.63$, $1.27,2.54 \mathrm{~cm})$ on drying of eggplant and reported the fastest drying times with the $0.63 \mathrm{~cm}$ thick slices. The trends reported by these researchers are similar to those obtained in the present study.

Table 3. Drying time and drying effectiveness of poultry manure.

\begin{tabular}{|c|c|c|c|c|c|c|}
\hline \multirow{2}{*}{$\begin{array}{l}\text { Drying } \\
\text { Temperature }\left({ }^{\circ} \mathrm{C}\right)\end{array}$} & \multirow{2}{*}{$\begin{array}{l}\text { Drying } \\
\text { Depth } \\
(\mathrm{cm})\end{array}$} & \multirow{2}{*}{$\begin{array}{l}\text { Drying } \\
\text { Time } \\
\text { (h) }\end{array}$} & \multicolumn{2}{|c|}{ Weight (g) } & \multirow{2}{*}{$\begin{array}{l}\text { Moisture } \\
(\mathrm{g})\end{array}$} & \multirow{2}{*}{$\begin{array}{l}\text { Drying } \\
\text { Effectiveness } \\
(\mathrm{h} / \mathrm{g})\end{array}$} \\
\hline & & & Initial & Final & & \\
\hline \multirow[t]{3}{*}{40} & 1 & 55 & 125.95 & 27.15 & 98.80 & 0.56 \\
\hline & 2 & 106 & 224.70 & 48.43 & 176.27 & 0.60 \\
\hline & 3 & 120 & 312.72 & 67.41 & 245.31 & 0.50 \\
\hline \multirow[t]{3}{*}{50} & 1 & 44 & 129.16 & 27.84 & 101.32 & 0.43 \\
\hline & 2 & 84 & 226.21 & 48.71 & 177.50 & 0.47 \\
\hline & 3 & 90 & 314.28 & 67.74 & 246.54 & 0.37 \\
\hline \multirow[t]{3}{*}{60} & 1 & 28 & 127.18 & 27.41 & 99.77 & 0.28 \\
\hline & 2 & 52 & 227.86 & 49.11 & 178.75 & 0.29 \\
\hline & 3 & 60 & 322.57 & 69.52 & 253.05 & 0.24 \\
\hline
\end{tabular}


Several researchers also studied the effect of drying temperature on the drying rate of various materials and reported faster drying rates at higher temperatures. Leonard et al. (2005) investigated the effect of temperature $\left(120,140\right.$ and $\left.160^{\circ} \mathrm{C}\right)$ on the drying rate of municipal sludge and reported the fastest rate of drying at $160^{\circ} \mathrm{C}$. Onider et al. (2010) studied the drying kinetics of rough rice at varying temperatures $\left(19-26^{\circ} \mathrm{C}\right)$ and observed the fastest drying rate at the highest temperature $\left(26^{\circ} \mathrm{C}\right)$. Panchariya et al. (2002) studied thin layer drying of black tea at various temperatures $\left(80-120^{\circ} \mathrm{C}\right)$ and reported the fastest drying rate at the highest temperature $\left(120^{\circ} \mathrm{C}\right)$. Gely and Santalla (2007) studied the effect of temperature $\left(50-90^{\circ} \mathrm{C}\right)$ on the drying rate of quinoa seeds and observed the highest drying rates at $90^{\circ} \mathrm{C}$. Brooks et al. (2008) investigated the effect of temperature $\left(55\right.$ and $\left.65^{\circ} \mathrm{C}\right)$ on the drying kinetics of tomato pieces of various geometries (whole, halves, quarters and eights) and found the fastest drying rates at $65^{\circ} \mathrm{C}$ for all geometries.

\subsection{Drying Effectiveness}

The drying effectiveness in this study is defined as the time required to drive off $1 \mathrm{~g}$ of moisture from the manure. The results (Table 3) showed that the difference in drying time between the shallower and deeper manure layers decreased as the temperature increased. However, when considering the drying effectiveness, the $3 \mathrm{~cm}$ manure depth was superior at all temperatures as less time was required to remove $1 \mathrm{~g}$ of water from the manure. The results also showed that more time was required to remove one gram of water from the manure at the $2 \mathrm{~cm}$ depth than those required at the 1 and $3 \mathrm{~cm}$ depths at all temperatures.

Ertekin and Yaldiz (2004) conducted a study into the thin layer drying of eggplant slices $(0.63,1.27$ and $2.54 \mathrm{~cm}$ thick) and found the most effective drying with $2.54 \mathrm{~cm}$ thick slices. However, significant increases in the depth of bed have been reported to decrease drying effectiveness. Nazghelichi et al. (2010) investigated the effect of bed depth $(30,60$ and $90 \mathrm{~mm})$ on the drying effectiveness of carrot cubes and found the optimum drying efficiency at $30 \mathrm{~mm}$ depth. Rao et al. (2007) investigated the thin layer drying of parboiled paddy at depths between 5 and $20 \mathrm{~cm}$ and reported optimum effectiveness with the lower depths in the range of 7-10 $\mathrm{cm}$. Akal et al. (2007) investigated the effect of bed depth $(10-30 \mathrm{~cm})$ and air temperature $\left(40,50\right.$ and $\left.60^{\circ} \mathrm{C}\right)$ on the effectiveness of thin layer drying of rough rice and found the effectiveness to decrease with increasing bed depth.

\subsection{Odor}

At the start of each experiment, the odor given off near the oven during the drying process was noticeable. However, as the drying process progressed, the presence and offensiveness of the odor decreased with the time and the final product (dried manure) did not have any offensive odor. The results (Table 4) of the organoleptic test performed on the dried manure $(3 \mathrm{~cm}$ deep manure layer at $60^{\circ} \mathrm{C}$ ) showed that both the presence and offensiveness of the odor were reduced by $65.3 \%$ and $69.3 \%$, respectively. The odor present in the dried manure was not found to be offensive $(23.3 \%$ of the panel members described the odor as that of grain, $20 \%$ described it as a mold musty, $13.3 \%$ described it as ammonia, $13.3 \%$ described it as sour/fermented, $6.7 \%$ described it as fish odor, $6.7 \%$ described it as yeast odor and $6.7 \%$ described it as sulfide/rotten eggs odor).

Welsh et al. (1977) reported a statistically significant decrease in odor after drying swine manure. Zhang et al. (2009) stated that the odor intensity was affected by the initial moisture content. They compared the odor emission in the initial phase of composting (24 hours) of broiler litter and found that nearly twice as much odorwas emitted at the $75 \%$ moisture content compared to $40 \%$ moisture content. Liao and Liang (2000) developed a mass transfer model which demonstrated that lower odor emissions occur when manure moisture is reduced due to the reduced advection that decreased the release of volatile fatty acids from the manure. Carey et al. (2004) reported that poultry manure odor was linked to ammonia volatization and could be eliminated through drying manure to a moisture content below $50 \%$.

Table 4. Odor rating (manure dried at $60^{\circ} \mathrm{C}$ and $3 \mathrm{~cm}$ depth).

\begin{tabular}{lcr}
\hline Parameter & Dried $^{\mathrm{a}}$ & Fresh \\
\hline Presence & $3.47 \pm 1.25$ & 10 \\
ffensiveness & $3.07 \pm 1.53$ & 10 \\
Description & & \\
Grain, Feed & 10 & - \\
Mold, Musty & 6 & - \\
Sour, Fermented & 4 & - \\
Yeast & 2 & - \\
Earth & 2 & - \\
Fish & 2 & - \\
Ammonia & 2 & 12 \\
Sulphide, Rotten Egg & 2 & 12 \\
Stagnant water & - & 3 \\
Rotten Cabbage & - & \\
\hline
\end{tabular}

* Total number of observations- 30 
Table 5. Manure characteristics.

\begin{tabular}{lcc}
\hline Parameter & Initial & Final $^{\mathrm{a}}$ \\
\hline Chemical Parameters & & \\
Moisture Content $(\%)$ & 77 & 14 \\
TKN (mg/kg) & 87970 & 39260 \\
Organic N (mg/kg) & 43940 & 30940 \\
Ammonium N (mg/kg) & 17450 & 8329 \\
pH & 8.4 & 6.6 \\
Bacteria $\left(10^{4}\right.$ cells/g) & 477000 & 620 \\
Yeast \& mold (cells/g) & 2700 & $<10$ \\
E. coli $\left(10^{4}\right.$ cells/g) & 2190 & $<10$ \\
Salmonellae & PD & $\mathrm{ND}^{\mathrm{c}}$ \\
Microbial Parameters & & \\
Protein $(\mathrm{g} / \mathrm{kg})$ & 43.32 & 41.59 \\
Calcium $(\mathrm{g} / \mathrm{kg})$ & 91.7 & 91.3 \\
Phosphorus $(\mathrm{g} / \mathrm{kg})$ & 24.8 & 24.5 \\
Potassium $(\mathrm{g} / \mathrm{kg})$ & 19.2 & 18.9 \\
N P K & $8.8,2.5,1.9$ & $3.9,2.5,1.9$ \\
Nutritional & &
\end{tabular}

a Dried at $60^{\circ} \mathrm{C}$ and $3 \mathrm{~cm}$ depth

b Partially Detected

c Not Detected

\subsection{Microbial Count}

The results of the microbial analyses are shown in Table 5. High numbers of bacteria $\left(477 \times 10^{7}\right.$ cells/g manure) and yeast and mould cells (2700 cells/g manure) were found in the raw manure. The drying process (a 3 $\mathrm{cm}$ deep layer at $60^{\circ} \mathrm{C}$ ) reduced the number of bacteria by $99.87 \%$ (from $477 \times 10^{7}$ to $620 \times 10^{4}$ cells $/ g$ manure), the yeast and mold cells by $99.63 \%$ (from 2700 cells/g to $<10$ cells/g) and E. coli by $99.56 \%$ (from $2290 \times 10^{4}$ cells/g to $<10 \times 10^{4}$ cells/g). Salmonellae was partially detected in the raw manure, but was not detected in the manure after drying at $60^{\circ} \mathrm{C}$ and $3 \mathrm{~cm}$ depth.

The metabolic activity, growth and survival of an organism are influenced by temperature and the killing action of heat is a time-temperature dependent process (Gradel et al., 2003). Practical procedures by which heat is employed are divided into two categories: (a) moist heat and (b) dry heat. There is a considerable difference in the moist and dry heat killing efficiencies of microorganisms. Moist heat destroys microorganisms through the denaturation of cellular proteins, facilitated by the presence of moisture. In contrast, dry heat dehydrates the cell and destroys microorganisms through the oxidation of intracellular constituents (Cutter, 2002). Hence, dry heat (or hot air) sterilization is recommended where it is either undesirable or unlikely that pressurized steam will make direct and complete contact with material to be sterilized.

Chang et al. (1974) reported that aerobic and anaerobic microbial counts were directly related to the moisture content of dehydrated cage layer samples and inversely related to the dehydration temperature. The authors observed that the aerobic and anaerobic microbial counts could be significantly reduced if the moisture content of the sample was reduced to less than $10 \%$.

Kim et al. (2012) studied the thermal inactivation of Salmonellae in broiler litter by dry heat and found that the temperature and moisture content affected the survival of Salmonellae in the litter. They found the time required for a $7 \mathrm{log}$ reduction in Salmonellae at $30 \%$ moisture content to be 80,78 and 44 min for the 70,75 and $80^{\circ} \mathrm{C}$ drying temperatures, respectively. When the initial moisture content of the broiler litter was increased from 30 to $50 \%$, the time required to achieve a $7 \log$ reduction was increased to 100,93 and $63 \mathrm{~min}$ at 70,75 and $80^{\circ} \mathrm{C}$ drying temperatures, respectively.

Watcharasukarn et al. (2009) evaluated the efficiency of pathogen removal by dry heat in dairy manure and found that $E$. coli was the most heat susceptible of the three organisms tested (E. coli, E. fecalis, C. perfringes). Sterilization (defined as a $10 \log$ reduction in viable cell count) times were found to be $5 \mathrm{~d}, 40 \mathrm{~min}$ and $10 \mathrm{~s}$ at 37 , 55 and $70^{\circ} \mathrm{C}$, respectively.

Elving (2009) observed a $3 \log$ reduction in the $E$. coli content of dairy manure after using dry heat for 60 $\min$ at $70^{\circ} \mathrm{C}$. The time needed for a $90 \%$ reduction in bacterial count was of 4.3, 1.5 and $0.5 \mathrm{~h}$ at 49,52 and $55^{\circ} \mathrm{C}$ respectively for Salmonellae.

\subsection{Manure $\mathrm{pH}$}

Heated air drying at $60^{\circ} \mathrm{C}$ and $3 \mathrm{~cm}$ depth caused a drop in $\mathrm{pH}$ from the initial value of 8.4 to 6.6 as shown in Table 5. The reduction in the $\mathrm{pH}$ was due to the loss of ammonium through the volatization process. Similar results were reported by other researchers. Lopez-Mosquera et al. (2008) observed a drop in $\mathrm{pH}$ (from 8.5 to 7.9 ) when drying poultry manure for pelletizing as fertilizer. Dikinya and Mufwanzala (2010) reviewed the literature and noticed lower $\mathrm{pH}$ values for dried poultry manure compared to those of fresh poultry manure. Sistani et al. (2001) investigated the changes in broiler litter $\mathrm{pH}$ after air drying, hot air drying (65 and $105^{\circ} \mathrm{C}$ ) and freeze drying and observed that hot air drying at $105^{\circ} \mathrm{C}$ resulted in a significant drop in manure $\mathrm{pH}$.

\subsection{Total Protein Content}

The results (Table 5) showed the total protein concentration of the dried manure $\left(60^{\circ} \mathrm{C}\right.$ and $3 \mathrm{~cm}$ depth) was $3.99 \%$ lower (reduction from 43.32 to $41.59 \mathrm{~g} / \mathrm{kg}$ ) than that of the raw manure. 
Cullison et al. (1976) found crude protein contents of air dried broiler and hen manure to be 34.5 and $40.4 \%$, respectively. However, other researchers reported much lower values. Torto and Rhule (1997) reported a decrease in crude protein content $(27-20 \%)$ in poultry manure after heated air drying $\left(80^{\circ} \mathrm{C}\right)$ and sun drying. Gihad (1976) reported a final crude protein content of $22.06 \%$ after forced air drying at $65^{\circ} \mathrm{C}$. El-Deek et al. (2009) dried poultry manure at $80^{\circ} \mathrm{C}$ and reported a final crude protein content of $19.10 \%$. Obasa et al. (2009) sun dried poultry manure and reported a final protein content of $28.6 \%$. The protein content of the dried poultry manure obtained in the present study is higher than the values reported in the literature, probably due to the lower drying temperature used in this study.

Protein is typically the largest and most expensive component of an animal diet. Protein provides the essential amino acids and nitrogen for the synthesis of non-essential amino acids and other nitrogen containing compounds (Snow and Ghaly, 2007; NRC, 1984). The dried poultry manure had a protein content of $422 \mathrm{~g} / \mathrm{kg}$ which exceeds the recommended dietary intake of animals (7.3-7.8 $\mathrm{g} / \mathrm{kg}$ ) reported by the NRC (1984).

\subsection{Elemental Analysis}

The results (Table 5) showed minimal losses of $0.4 \%$ in calcium (from 90.7 to $90.13 \mathrm{~g} / \mathrm{kg}$ ), $1.2 \%$ in phosphorus (from 24.8 to $24.5 \mathrm{~g} / \mathrm{kg}$ ) and $1.6 \%$ in potassium (from 19.2 to $18.9 \mathrm{~g} / \mathrm{kg}$ ) due to drying of poultry manure at $60^{\circ} \mathrm{C}$ and $3 \mathrm{~cm}$ depth. These reductions are within the experimental errors. Patterson and Lorenz (1996) reported a slight increase in calcium content after air drying. Nicholson et al. (1996) reported an increase in phosphorus content of various poultry manures after air drying. The potassium content of dried poultry manure obtained in this study was in the range reported by Nicholson et al. (1996) and lower than that reported by Moreno-Caselles et al. (2002).

The total Kjeldahl nitrogen, organic nitrogen and ammonium nitrogen contents of the manure were reduced by $55.37 \%$ (from 87.97 to $39.26 \mathrm{~g} / \mathrm{L}$ ), $29.58 \%$ (from 43.94 to $30.94 \mathrm{~g} / \mathrm{L}$ ) and $52.26 \%$ (from 17.45 to $8.33 \mathrm{~g} / \mathrm{L}$ ), respectively as shown in Table 5. The large losses in nitrogen content were due to ammonia volatization during the drying process. Similar results were reported by Nicholson et al. (1996). The total nitrogen content obtained in the present study is within the range of nitrogen contents reported by other researchers (Nicholson et al., 1996; Lopez-Mosquera et al., 2008; Moreno-Caselles et al., 2002; Patterson and Lorenz, 1996).
Although the phosphorus and potassium contents remained relatively unchanged in the dried poultry manure, the loss of nitrogen during the drying process changed the NPK ratio of the poultry manure from 8.8 : 2.5: 1.9 to 3.9: 2.5:1.9 (Table 5). The dried poultry manure NPK ratio in this study falls within the range of NPK ratios reported in the literature for dried poultry manure Patterson and Lorenz (1996) reported an NPK ration of 1.8: 2.7: 1.6 for dried hen manure. The low nitrogen content (relative to the current study) may be due to the 4-6 week storage of poultry manure in the poultry houses before sampling, which allowed for increased volatization of ammonia. Nicholson et al. (1996) reported poultry manure NPK ratios of $6: 2: 2$ and $6: 2: 3$ after air drying. Moreno-Caselles et al. (2002) reported an NPK value of 3.1: 3.0:3.0 for dried chicken manure.

Yavinder-Singh et al. (2009) reported improved growth to rice and wheat crops when fertilized with poultry manures with NPK ratios of 1.9: 1.6: 1.9. Poultry manures are preferred over other animal manures for use as fertilizers due to their higher contents of readily available potassium and phosphorus (Nicholson et al., 1996; Moreno-Caselles et al., 2002).

\subsection{Drying Manure in a Solar Dryer}

Assuming that the average temperature in the drying chamber is $60^{\circ} \mathrm{C}$ and the moisture content of the manure to be dried is $78.44 \%$ as in the experiment, the amount of manure that will be fed into the dryer using a $3 \mathrm{~cm}$ deep layer can be calculated as follows:

$\mathrm{W}_{\mathrm{D} 3}=\frac{\mathrm{A}_{\mathrm{D} 3} \times \mathrm{W}_{\mathrm{T} 3}}{\mathrm{~A}_{\mathrm{T} 3}}$

Where:

$\mathrm{W}_{\mathrm{D} 3}=$ weight of manure to be fed into the solar dryer for a $3 \mathrm{~cm}$ deep layer $(\mathrm{g})$

$A_{D}=$ surface area of the drying chamber in the solar dryer $\left(\mathrm{cm}^{2}\right)$

$\mathrm{W}_{\mathrm{T} 3}=$ weight of the manure in $3 \mathrm{~cm}$ deep drying tray (g)

$\mathrm{A}_{\mathrm{T} 3}=$ surface area of the $3 \mathrm{~cm}$ deep drying tray $\left(\mathrm{cm}^{2}\right)$

The manure index $\left(D_{M}\right)$ is defines in this study as the amount of manure that can be dried per hour. $D_{M}$ can be calculated for the $3 \mathrm{~cm}$ deep manure layer as follows:

$\mathrm{D}_{\mathrm{M} 3}=\frac{\mathrm{A}_{\mathrm{D}} \times \mathrm{W}_{\tau 3}}{\mathrm{~A}_{\tau} \times \theta}$

Where: 
$\mathrm{D}_{\mathrm{M} 3}=$ the manure index for the $3 \mathrm{~cm}$ deep manure layer $(\mathrm{kg} / \mathrm{h})$

$\Theta \quad=$ The time required to dry the manure in the $3 \mathrm{~cm}$ deep drying tray at $60^{\circ} \mathrm{C}(\mathrm{h})$

In this study $\theta$ and $D_{\mathrm{M} 3}$ were estimated to be $60 \mathrm{~h}$ and $336 \mathrm{~kg} / \mathrm{h}$, respectively. The required area was estimated from Eq. 7 and Eq. 9 as approximately $2.50 \mathrm{~m}^{2}$. A rectangular collector of $2.1 \mathrm{~m}$ in length and $1.2 \mathrm{~m}$ in width (with an area of $2.52 \mathrm{~m}^{2}$ ) was selected and passive solar poultry manure dryer was constructed. The passive solar poultry manure dryer (Fig. 3) consisted of three components: the hopper, the feeding system and the drying chamber. In operation, the equipment is positioned with the width along the east-west axis and the solar collector facing south.

\subsubsection{Hopper}

The hopper was designed as a funnel shaped reservoir from which the manure is discharged on to the drying unit located at its base. It was made of 18 gauge galvanized sheet metal. The upper section of the hopper resembled a cube having dimensions of 120,50 and 60 $\mathrm{cm}$ for the lengths, width and depth, respectively. Three of the sides were pop riveted together using $1610 \mathrm{~mm}$ pop rivets, spaced $75 \mathrm{~mm}$ apart. The fourth side (removable section) was held in place with 6 machine screws, 3 placed equidistant on each end. The lower section of the hopper had dimensions at the bottom end of 120,10 and $40 \mathrm{~cm}$ for the length, width and depth, respectively. The angle of incline of the lower section of the hopper was $28^{\circ}$ to the vertical. The bottom was closed with a sliding gate that was manually opened during feeding.

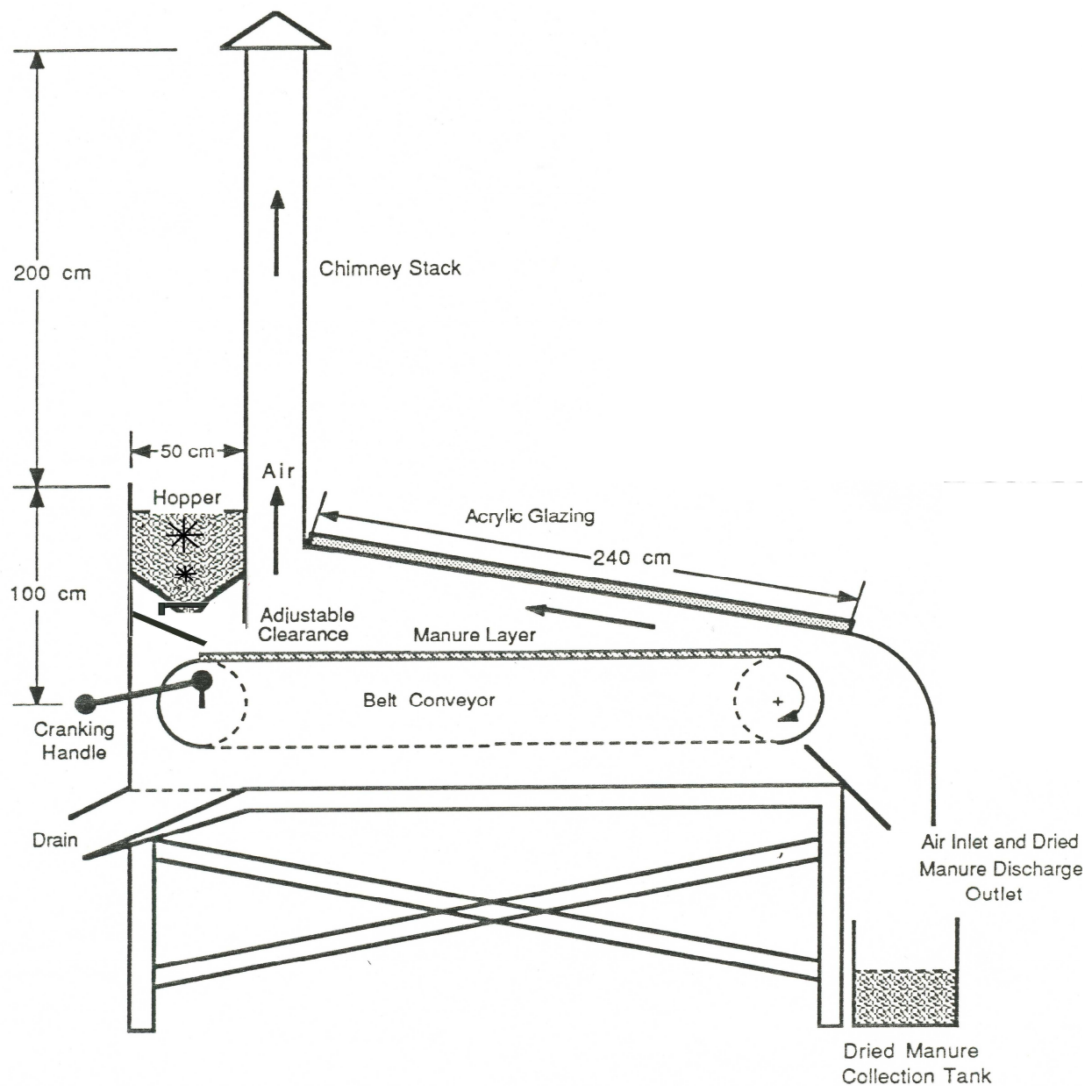

Fig. 3. A passive solar manure dryer 
The biggest problem that was encountered during operation was the difficulty of feeding manure freely into the dryer without applying force on the manure which also compressed the manure and made it difficult to press through. Use of agitators was found to be necessary to prevent manure from settling and consolidation in the hopper. Therefore, two agitators were used to loosen and mix the manure in the hopper in order to keep it homogeneous and easily flowing. The agitators were made of $25 \mathrm{~mm}$ diameter steel shaft with wire wrapped around them 4 turns and extended to form spikes as shown in Fig. 4. There were small holes drilled in the end of the shaft for the wrapped ends of the wired to prevent them from rotating around the shaft. As the force of resistance of the manure tries to wrap the wires around the shaft, the wires tighten themselves onto the shaft. The upper agitator had 8 music gauge wires extending 17 $\mathrm{cm}$ radially whereas the lower agitator had 9 music gauge wires extending $8 \mathrm{~cm}$ radially. To support the agitator shafts at the end, non-expansion 2-bolt pillow blocks (lubricated with grease) were used. These pillow blocks were bolted onto horizontal angle iron supports using two $14 \mathrm{~mm}$ x $50 \mathrm{~mm}$ UNC bolts and hex nuts each.

\subsubsection{Feeding System}

The feeding system consisted of two sets of chains mounted on two pairs of sprockets on both sides of the dryer. The chain links were interconnected by a series of flat galvanized steel slats that form the drying bed.

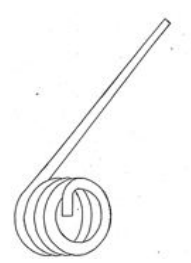

a) Wire Spike

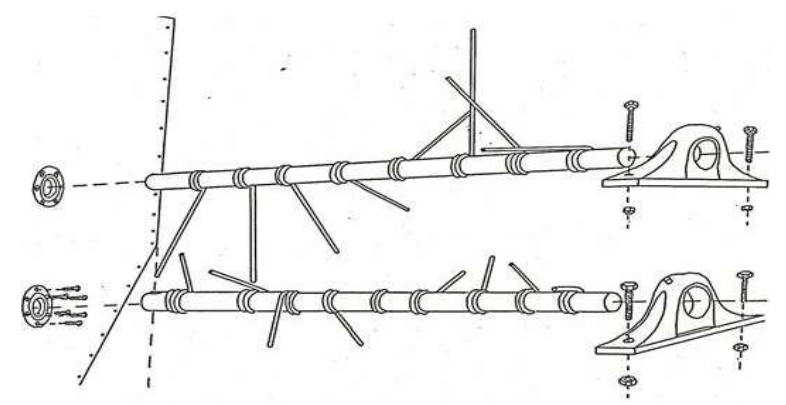

b) Shaft with Spikes

Fig. 4. Manure agitators
The chain slats passed just below the base of the hopper and into the drying chamber. The slats were moved manually using a crankshaft with a handle to rotate the sprockets. One of the sprockets was connected to the agitators by chains. At the end of each drying batch, cranking of the handle allowed for the discharge of the dried manure through the outlet into the manure collection bucket, while recharging the drying chamber with a fresh batch of homogeneous manure from the hopper.

\subsubsection{Drying Chamber}

The drying chamber consisted of the drying bed of chain slats over which an acrylic glazing of $216 \mathrm{~cm}$ long, $120 \mathrm{~cm}$ wide and $0.6 \mathrm{~mm}$ thick was mounted. A chimney stack of $25 \mathrm{~cm}$ diameter and $200 \mathrm{~cm}$ height with an air inlet was provided. The difference in temperature between the air in the drying chamber and the ambient air induced air flow by natural convection. This facilitated the removal of moisture that evaporated from the manure in the drying chamber.

\section{CONCLUSION}

At the three temperature levels studied, the time required to dry poultry manure in the $1 \mathrm{~cm}$-deep layer was the least, followed by the 2 and $3 \mathrm{~cm}$-deep layers, respectively. The optimum depth to dry manure (at which the highest amount of moisture is removed in the shortest amount of time) was $3 \mathrm{~cm}$. The manure drying rate increased with increasing temperature and was the fastest at $60^{\circ} \mathrm{C}$ for all manure depths studied. A drying temperature-manure depth combination of $60^{\circ} \mathrm{C}$ and 3 $\mathrm{cm}$ was the most efficient for the thin layer drying of poultry manure. Drying poultry manure at $60^{\circ} \mathrm{C}$ and 3 $\mathrm{cm}$ depth provides an effective means of removing moisture and odor and destroying microorganisms, thereby enabling the production of a value added product. This temperature range is feasible with a solar dryer operating in the tropics. Based on the heat and mass analyses, a solar dryer operating at a $3 \mathrm{~cm}$ depth and $60^{\circ} \mathrm{C}$ would be capable of drying $336 \mathrm{~kg} / \mathrm{h}$. Drying poultry manure with solar heated air resulted in a slight decrease in protein content (from 42 to $41 \%$ ), a decrease in $\mathrm{pH}$ (from 8.4 to 6.6), total removal of Salmonellae and a $99 \%$ reduction of bacteria, yeast, mold and E. coli. Thin layer solar drying of poultry manure proved to be an effective means of converting poultry manure into a value added product (organic fertilizer or animal feed) while reducing the environmental and health problems associated with current disposal options. 


\section{ACKNOWLEDGEMENT}

This research was funded by the Natural Science and Engineering Research Council (NSERC) of Canada.

\section{REFERENCES}

Akal, C., O. Candan, E. Koralay, F. Chen and R. Oberhänsli, 2007. geochemistry, geochronology and tectonic setting of early triassic metavolcanics of the afyon zone, Turkey.

Alam, M.S., M.J. Khan, M.A. Akber and M. Kamruzzaman, 2008. Broiler litter and layer manure in the diet of growing bull calves. Bangladesh Veterinarian, 25: 62-67. DOI: 10.3329/bvet.v25i2.4619.

Amine-Khodja, A., C. Richard, B. Lavedrine, G. Guyot, O. Trubetskaya and O. Trubetskoj, 2006. Water-soluble fractions of composts for the photodegradation of organic pollutants in solar light Chemistry Letters, 3: 173-177. DOI: 10.1007/s10311-005-0028-8.

Amon, B., V. Kryvoruchko, T. Amon and S. Zechmeister-Boltenstern. 2006. Methane, nitrous oxide and ammonia emissions during storage and after application of dairy cattle slurry and influence of slurry treatment. Agriculture, Ecosystems and Environment, 112: 153-162. DOI: 10.1016/j.agee.2005.08.030.

APHA, 1998. Standard Methods for the Examination of Water and Wastewater. American Public Health Association, Washington, DC. USA., ISBN: 0875530915 , pp: 1134.

ASABE, 2009. Standards. 55th Edn., American Society of Agricultural and Biological Engineers, Saint Joseph, MI. USA. ISBN: 87551187, pp: 1168.

Axtell, R.C., 1999. Poultry integrated pest management: Status and future. Integrated Pest Management Reviews, 4: 53-73. DOI: 10.1023/A:1009637116897.

Benali, M. and T. Kudra, 2002. Thermal dewatering of diluted organic suspensions: Process mechanism and drying kinetics. Drying Technology, 20: 935-951. DOI: $10.1081 /$ DRT-120003770.

Bernhart, M. and O.O. Fasina, 2009. Moisture effect on the storage, handling and flow properties of poultry litter. Waste Management, 29: 1392-1398. DOI: 10.1016/j.wasman.2008.09.005.

Berry, E.D. and D.N. Miller, 2005. Cattle feedlot soil moisture and manure content. Journal of Environmental Quality, 34: 656-663. DOI: 10.2134/jeq 2005.0656

Brock, T.D. and M.T. Madigan, 1991. Biology of Microorganisms. 6th Edn., Prentice Hall, Englewood Cliffs, New Jersey, ISBN-10: 0130838179, pp: 874.
Brooks, M. S., N. H. Abou El-Hana and A. E. Ghaly. 2008. Effects of tomato geometries and air temperature on the drying behavior of plum tomato. American Journal of Applied Sciences, 5: 1369-1375. DOI: 10.3844/ajassp.2008.136 9.1375.

Carey, J.B., R.E. Lacey and S. Mukhtar, 2004. A review of literature concerning odors, ammonia and dust from broiler production facilities: 2. Flock and house management factors. Journal of Applied Poultry Research, 13: 509-513.

Chang, T.S., D. Dorn and H.C. Zindel, 1974. Stability of poultry anaphage. Poultry Science, 5: 2221-2224. DOI: $10.3382 /$ ps.0532221.

Choi, H.L., T.L. Richard and H.K. Ahn, 2001. Composting high moisture materials: Biodrying poultry manure in a sequentially fed bioreactor. Compost Science and Utilization, 9: 303-311.

Cullison, A.E., H.C. McCampbell, A.C. Cunningham, R.S. Lowrey and E.P. Warren et al., 1976. Use of poultry manures in steer finishing rations. Journal of Animal Science, 42: 219-228.

Cummings, R.J. and W.J. Jewell, 1977. Thermophilic Aerobic Digestion of Dairy Waste. In: Food, Fertilizer and Agricultural Residues, Loehr, R.C. (Eds.). Ann Arbor Science Publishers Inc, Michigan, Illinois, ISBN: 9780250401901.

Cutter, C.N., 2002. Microbial control by packaging: A review. Critical Reviews in Food Science and Nutrition, 42: 151-161. DOI: $10.1080 / 10408690290825493$.

Diamante, L.M. and P.A. Munro, 1993. Mathematical modelling of the thin layer solar drying of sweet potato. Solar Energy, 51: 271-276. DOI: 10.1016/0038-092X(93)90122-5.

Dikinya, O. and N. Mufwanzala, 2010. Chicken manure-enhanced soil fertility and productivity: Effects of application rates. Journal of Soil Science and Environmental Management, 1: 46-54.

Duffie, J.A. and W.A. Beckman, 1980. Solar Engineering of Thermal Processes. 3rd Edn., John Wiley and Sons, New York, USA., ISBN-10: 0471050660, pp: 928.

El-Deek, A.A., K.M. Ghonem, S.M. Hamdy, M.A. Aser and F.M. Aljassas et al., 2009. Production of single cell protein from poultry manure and evaluation of broiler chickens diets. International Journal of Poultry Science, 8: 1062-1077. DOI: 10.3923/ijps.2009.1062.1077.

El-Sayed, H.S., 1992. Solar drying of poultry manure for animal feed under simulated Egyptian conditions. unpublished Ph.D. Thesis, Cairo University, Giza, Egypt. 
Elving, J., 2009. Pathogenic inactivation and regrowth in organic waste during biological treatment. Licentiate Thesis, Swedish University of Agricultural Sciences, Uppsala, Sweeden.

Ertekin, C. and O. Yaldiz, 2004. Drying of eggplant and selection of a suitable thin layer drying model. Journal of Food Engineering, 63: 349-359. DOI: 10.1016/j.jfoodeng.2003.08.007.

Fares, F., A. Albalkhi, J. Dec, M. A. Bruns and J. Bollag. 2005. Physicochemical characteristics of animal and municipal wastes decomposed in arid soils. Journal of Environmental Quality, 34: 1392-1403.

Fugere, M., P. Farand, R. Chabot and P. Stuart, 2007. Design and techno-economic analysis of a process for transforming pig manure into a value-added product. The Canadian Journal of Chemical Engineering, $\quad 85$ : 360-368. DOI: $10.1002 /$ cjce. 5450850311 .

Ghaly, A.E. and K.N. MacDonald, 2012. Kinetics of thin layer drying of poultry manure. Am. J. Biochem. Biotechnol., $\quad 8$ : 128-142. DOI: 10.3844/ajbbsp.2012.128.142

Gely, M.C. and E.M. Santalla, 2007. Moisture diffusivity in quinoa (Chenopodium quinoa Willd.) seeds: Effect of air temperature and initial moisture content of seeds. Journal of Food Engineering, 78: 1029-1033. DOI: 10.1016/j.jfoodeng.2005.12.015.

Gihad, E.A., 1976. Value of dried poultry manure and urea as protein supplements for sheep consuming low quality tropical hay. Journal of Animal Sciences, 42: 705-709.

Gradel, K.O., J.C. Jorgensen, J.S. Andersen and J.E.L. Corry, 2003. Laboratory heating studies with Salmonella spp. and Escherichia coli in organic matter, with a view to decontamination of poultry houses. Journal of Applied Microbiology, 94: 919-928. DOI: 10.1046/j.1365-2672.2003.01933.x.

Iannotti, D.A., M.E. Grebus, B.L. Toth, L.V. Madden and H.A.J. Hoitink, 1994. Oxygen respirometry to assess stability and maturity of composted municipal solid waste. Journal of Environmental Quality, 23: 1177-1183.

Kim, J., J. Diao, M.W. Shepherd Jr., R. Singh and S.D. Heringa et al., 2012. Validating thermal inactivation of Salmonella spp. in fresh and aged chicken litter. Applied and Environmental Microbiology, 78: 1302-1307. DOI: 10.1128/AEM.06671-11.

Lay, Jr. D.C., R.M. Fulton, P.Y. Hester, D.M. Karcher and J.B. Kjaer et al., 2011. Hen welfare in different housing systems. Poultry Science, 90: 278-294. DOI: $10.3382 /$ ps.2010-00962.
Leonard, A., S. Blacher, P. Marchot, J.P. Pirard and M. Crine, 2005. Convective drying of wastewater sludges: Influence of air temperature, superficial velocity and humidity on the kinetics. Drying Technology, 23: 1667-1679. 10.1081/DRT-200065082.

Liao, C.M. and H.M. Liang, 2000. Modeling effects of moisture content and advection on odor causing vocs volatilization from stored swine manure. Journal of Environmental Science and Health, Part B: Pesticides, Food Contaminants, and Ag-ricultural Wastes, 53: 357-378. DOI: 10.1080/03601230009373276.

Liu, B.Y.H. and R.C. Jordan, 1960. The interrelationship and characteristic distribution of direct, diffuse and total solar radiation. Solar Energy, 4: 1-19. DOI: 10.1016/0038-092X(60)90062-1.

Lopez-Mosquera, M.E., F. Cabalerio, M.J. Sainz, A. Lopes-Fabal and E. Carral, 2008. Fertilizing value of broiler litter: Effects of drying and pelletizing. Bioresource Technology, 99: 5626-5633. DOI: 10.1016/j.biortech.2007.10.034.

Martens, W. and R. Bohm, 2009. Overview of the ability of different treatment methods for liquid and solid manure to inactivate pathogens. Bioresource Technology, 100: 5374-5378. DOI: 10.1016/j.biortech.2009.01.014.

Maskan, A., S. Kaya and M., Maskan, 2002. Hot air and sun drying of grape leather (pestil). Journal of Food Engineering, 54: 81-88. DOI: 10.1016/S0260-8774(01)00188-1.

McCaskey, T.A. and Y.D. Wang, 1985. Evaluation of the lactic acid fermentation process for elimination of mycobacteria from wastelage. Journal of Dairy Science, 63: 1401-1408. DOI: 10.3168/jds.S0022-0302(85)80976-0.

Moreno-Caselles, J., R. Moral, M. Perez-Murcia, A. Perez-Ezpinosa and B. Rufete, 2002. Nutrient value of animal manures in front of environmental hazards. Communications in Soil Science and Plant Analysis, 33: 3023-3032. DOI: 10.1081/CSS-120014499.

Nazghelichi, T., M.H. Kianmehr and M. Aghbashlo, 2010. Thermodynamic analysis of fluidized bed drying of carrot cubes. Energy, 35: 4679-4684. DOI: 10.1016/j.energy.2010.09.036.

Nellist, M.E., 1987. Modelling the performance of a cross-flow grain drier. Journal of Agricultural Engineering Research, 37: 43-57. DOI: 10.1016/0021-8634(87)90130-2. 
Nicholson, F.A., B.J. Chambers and K.A. Smith, 1996. Nutrient composition of poultry manures in England and Wales. Bioresource Technology, 58: 279-284. DOI: 10.1016/S0960-8524(97)86087-7.

NRC, 1984. Nutrient Requirements for Domestic Animals: Nutrient Requirements of Beef Cattle. 6th Edn., National Academy Press, Washington D.C., USA., ISBN: 0309034477, pp: 90.

Obasa, S.O., W.O. Alegbeleye and J.B. Amole, 2009. Dried poultry manure meal as a substitute for soybean meal in the diets of african catfish (Clarias gariepinus) (Burchell 1822) advanced fry. Turkish Journal of Fisheries and Aquatic Sciences, 9: 121-124.

Onider, G.O., T.J. Siebenmorgen and A. Mauromoustakos, 2010. Low-temperature, low-relative humidity drying of rough rice. Journal of Food Engineering, 100: $\quad 545-550$. DOI: 10.1016/j.jfoodeng.2010.05.004.

Panchariya, P.C., D. Popovic and A.L. Sharma, 2002. Thin-layer modelling of black tea drying process. Journal of Food Engineering, 52: 349-357. DOI: 10.1016/S0260-8774(01)00126-1.

Patterson, P.H. and E.S. Lorenz, 1996. Manure nutrient production from commercial white leghorn hens. $\mathrm{J}$ The Journal of Applied Poultry Research, 5: 260-268.

Pel, R., R. Oldenhuis, W. Brand, A. Vos and J.C. Gottschal et al., 1997. Stable-Isotope analysis of a combined nitrification-denitrification sustained by thermophilic methanotrophs under low-oxygen conditions. Applied Environmental Microbiology, 63: 474-481.

Rao, P.S., S. Bal and T.K. Goswami, 2007. Modelling and optimization of drying variables in thin layer drying of parboiled paddy. Journal Food Engineering, 78: 480-487. DOI: 10.1016/j.jfoodeng.2005.10.019.

Sistani, K.R., D.M. Miles, D.E. Rowe, G.E. Brink and S.L. McGowen, 2001. Impact of drying method, dietary phosphorus levels and methodology on phosphorus chemistry of broiler manure. Communications in Soil Science and Plant Analysis, 32: 2738-2793. DOI: 10.1081/CSS-120000961.

Snow, A.M. and A.E. Ghaly, 2007. The nutrition value of wastewater grown barley and it's utilization in fish feed. American Journal of Agriculture and Biological Science, 2: 168-183. DOI: 10.3844/ajabssp.2007.159.167.
Thomas, J.W., Y.Y.P. Tinnimitt and H.C. Zindel, 1972. Dehydrated poultry waste as a feed for milking cows and growing sheep. Journal of Dairy Science, 55: 1261-1265.

DOI: 10.3168/jds.S0022-0302(72)85659-5.

Tiris, C., N. Ozbalta, M. Tiris and I. Dincer, 1994. Experimental testing of a new solar dryer. International Journal of Energy Research, 18: 483-491. DOI: 10.1002/er.4440180407.

Torto, R. and S.W.A. Rhule, 1997. Performance of West African dwarf goats fed dehydrated poultry manure as a dry season supplement. Tropical Animal Health and Products, 29: 180-184. DOI: 10.1007/BF02633020.

Watcharasukarn, M., P. Kaparaju, J.P. Steyer, K.A. Krogfelt and I. Angelidaki, 2009. Screening Escherichia coli, Enterococcus faecalis and Clostridium perfringens as indicator organisms in evaluating pathogen-reducing capacity in biogas plants. Environmental Microbiology, 58: 221-30. DOI: 10.1007/s00248-009-9497-9.

Welsh, F.W., D.D. Schulte, E.J. Kroeker and H.M. Lapp, 1977. The effect of anaerobic digestion upon swine manure odors. Canadian Agricultural Engineering, 19: 122-126.

Yavinder-Singh, R.K. Ghupta, H.S. Thind, Bijay-Sing and Varinderpal-Singh et al., 2009. Poultry litter as a nitrogen and phosphorous source for the rice-wheat cropping system. Biology and Fertility of Soils, 45: 701-710. DOI: 10.1007/s00374-009-0373-z

Zhang, W. and A. Lau, 2007. Reducing ammonia emission from poultry manure composting via struvite formation. Journal of Chemical Technology and Biotechnology, 82: 598-602. DOI: 10.1002/jctb.1701.

Zhang, W., A.K. Lau and Z.S. Wen, 2009. Preventive control of odor emissions through manipulation of operational parameters during the active phase of composting. Journal of Environmental Science and Health, Part B: Pesticides, Food Contaminants, and Agricultural Wastes, 44: 496-505. DOI: $10.1080 / 03601230902935451$. 